\title{
Papeles de Europa
}

ISSN-e 1989-5917

Intercultural Europe: Cultural Diversity in the EU and the Debate on a Common European Cultural Identity

Jordi-Jesús Muñoz ${ }^{1}$

Fecha de recepción: octubre de 2017. Fecha de aceptación: diciembre de 2017

\begin{abstract}
The aim of the work is to approach the complex cultural system of the European Union through the analysis of cultural diversity within the EU and the existence of a possible common European cultural identity. This paper attempts to promote the debate on intercultural dialogue in the European Union and the actions undertaken by the European institutions to promote a common cultural identity based on plurality and diversity.

Key words: European cultural identity; cultural diversity; interculturalism; intercultural dialogue; cultural policies.

\section{Europa Intercultural: Diversidad Cultural en la Unión Europea y el Debate sobre una Identidad Cultural Europea Común}

Resumen. El objetivo de este trabajo es hacer una aproximación al complejo sistema cultural de la Unión Europea a través del análisis de la diversidad cultural dentro de la UE y la existencia de una posible identidad cultural europea común. Se pretende así promover el debate sobre el diálogo intercultural en la Unión Europea y las acciones emprendidas por las instituciones europeas para promover una identidad cultural común basada en la pluralidad y la diversidad.

Palabras clave: Identidad cultural europea; diversidad cultural; interculturalismo; diálogo intercultural; políticas culturales.

JEL: F53, K33, N44 y Z10

\section{Introduction}

The European Union is more than the creation of a common economic space. Europe aspires to a political union, capable of awakening a sense of identity and belonging. The reality of a political community depends not only on the existence of a project structured around legal elements — such as separation of powers, judicial guarantees, participation from citizens or the decision-making process - but also depends on the strength of the bond that constitutes that community.

The voices that have been calling for a European construction not only in the economic sphere, but also in the cultural dimension have intensified in recent years, while significant steps have been taken towards a political union and new concepts have been formulated, such as the European citizenship. This concept goes beyond the market and affect the feeling of belonging, loyalty and identity, and it is based not only on the economic and political but also the cultural order. In these circumstances, the cultural issue, which affects the collective symbolic imaginary, becomes essential for the future of the European political project.

We are currently in a complicated context. The still visible economic crisis, the Brexit or the raise of the fair right and nationalism, among others, exemplify the convulsive situation that crosses the Union and that have questioned the strength of the European political project. In that sense, precisely one of the ways to strengthen the European project is through the defense of common values represented by the EU and through the common identity that unites all its Member States. However, that may be more complex than it seems. First of all, one must ask whether there is a European 
identity, a common culture. One important aspect of cultural identity is shared histories or common memories. Such histories can be presented by heritage, that is those traces of the past a society chooses to preserve.

Nevertheless, heritage is not the only element that constitutes the cultural identity of a society. Indeed, cultural identity can be seen through several prisms, such as geopolitics, geography, religion, ethnicity, language or even political or social values. It is a sensitive issue that must be addressed in many areas.

From here, many issues come to the fore. This paper aims to answer the following questions: Can a multicultural space such as the EU have a common cultural identity? How does the EU work on this path? The main objective of this work is not to cover or to solve the debate surrounding the European cultural identity; what is intended is to make a first approximation to the subject and provide a basis to understand the main features of concepts such as cultural identity, interculturalism or cultural diversity and observe how they are applied within the EU.

Starting from there, we assume that the EU, as a multicultural and intercultural space, is endowed with political and legal instruments to respond to its cultural reality and follows the principle of respect for diversity through its protection and promotion. Furthermore, we also assume that the EU has developed a series of policies and strategies for the reinforcement of a common European cultural identity.

As for the methodology, this work will be divided into three sections: the first consists in the analysis of the cultural system in the EU and its features; then, we will approach to the concept of cultural identity and how it can fit in the context of the EU. This will be a first approach and introduction to the two main sections: the one dedicated to cultural diversity and its legal bases in the EU and the other one dedicated to the political actions by the organization in matters of cultural identity.

The second section, as said, will focus on the recognition of the cultural diversity within the EU and a first approach to the instruments that the EU has to defend and protect its cultural diversity. Once having defined this, the third section will focus on the EU strategies to strengthen the sense of cultural identity through the analysis of some cultural policies and some projects in which the EU works to enhance that common cultural identity based on the respect and the intercultural dialogue

\section{Conceptual framework}

2.1. The cultural system in the EU. Multiculturalism vs. interculturalism

The EU is a conglomeration of very culturally diverse states and regions within themselves and between them. European societies and the EU are multicultural. This concept has a descriptive meaning and it is a neutral term that refers to cultural diversity in a specific territory. It seems clear, then, that the Member States of the Union are conformed by multicultural societies and so are they and so is the EU.

Going further, there is another meaning for the term multiculturalism that goes beyond the mere description of a diverse society. Multiculturalism is also a normative response in a propositional sense, it refers to an aspiration ${ }^{2}$. In a multicultural territory, multiculturalism seeks to ensure that all cultures inside a society are respected and can coexist peacefully without renouncing their cultural identity. According to Javier de Lucas ${ }^{3}$, multiculturalism is not a natural phenomenon and response to a multicultural situation; it is a proposal made from a value judgement. Multiculturalism has been seen hazardous because it can become, in practice, a merely peaceful - if not benevolent - coexistence, in any case separated or juxtaposed of different cultures in the same territory, likely to lead to uneven distributions of positions.

On the other hand, there is interculturalism ${ }^{4}$. This is a different paradigm from multiculturalism which proposal is to avoid the previous risk: the deficit in the legitimacy of the distribution of resources and political representation; inequality in terms of material and symbolic positions; and especially the lack of communication between different cultures. Unlike multicultural territories — which are many-, it is difficult to find descriptions of intercultural territories. Interculturalism seems to refer to a desire, a management model. In-

LuCAS, JAVIER DE (2006), "Sobre la gestación de la multiculturalidad que resulta de la inmigración" in SERAFí, J., GimeNo, C. (ed.), Migración e interculturalidad. De lo local a lo global, Castellón de la Plana, Universitat Jaume I, 34-59. Idem, op. cit., p. 39.

Idem, op. cit., p. 43. 
terculturalism seems to mean equal respect - it takes the idea of respect very seriouslyand understands cultural pluralism and diversity through the positive affirmation of the value of cultural differences.

The intercultural proposal is the possibility of moving towards a society or territory - also a state or, in this case, a supranational organization as the EU- that is pluralistic and pluralist and where the concept of "identity" is not a translation of the manners and signs of a hegemonic group in terms of material power or symbolic or political representation. Instead of that, interculturalism means the design of public spaces and institutions that are sensitive to differences. A demanding political space with the proscription of all discrimination.

Indeed, the EU seems to be - besides its intrinsically multiculturalism - more intercultural than multicultural. On paper, the EU relies on pluralist structures that demand respect for cultural diversity. Its horizon explicitly abandons multicultural management models that promote discrimination, assimilation or homogenization - neither of national immigrants from third countries nor of cultural minorities ${ }^{5}$ -

Pluralist political spaces have an obligation to respect but also - and very important - to promote cultural diversity, for example by adapting public spaces and regulating issues of civil law, combating pedagogical but also criminal negative stereotypes about ethnic minorities — such as gypsies-, stimulating their presence in public institutions or also increasing adaptability on the workplaces, hospitals or public spaces according to different religious and cultural uses. Other actions might be sanctioning manifestations of hatred against persecuted minorities, protecting the teaching of minority religions or traditions or measures against the incitement to xenophobia or any kind of discrimination. Furthermore, interculturalism is also characterized by promoting an open and diverse legal societies and in the legal plane by adopting public policies based on the recognition of individual and collective rights respecting or better valuing cultural diversity.

\footnotetext{
More in: Dobbernack, J., Modood, T. (2011), "Tolerance and cultural diversity in Europe: theoretical perspectives and contemporary developments" in Tolerance, pluralism and social cohesion: responding to the challenges of the $21^{\text {st }}$ century in Europe - ACCEPT PLURALISM, Florence, European University Institute, pp. 36-50.
}

Therefore, we can see that the EU better fits in the intercultural proposal.

\subsection{European cultural identity: a complex issue}

We have seen that the EU seems to participate from an intercultural model —whose legal and political bases we will see later-. That means that the EU prides itself on its cultural diversity and seeks to protect and promote it through respect, equality and dialogue. Certainly, the EU is shaped by many different cultural identities. But does the EU have its own cultural identity? To respond to this, we must know well what the concept of cultural identity means.

Cultural identity ${ }^{6}$ is the identity or feeling of belonging to a group. It is part of a person's self-conception and self-perception and is related to nationality, ethnicity, religion, social class, generation, locality or any kind of social group that has its own distinct culture. In this way, cultural identity is both characteristic of the individual but also of the culturally identical group of members sharing the same identity. In recent decades, a new form or identification has emerged which identifies a collection of various cultural identifiers that may be the result of various conditions including location, gender, race, history, nationality, language, religion, beliefs, aesthetics or even food.

According to Jana Peterková 7 , identity can be considered as historical identity - selecting those important moments of the past, thus creating a socio-cultural, natural and economic heritage for the sake of the community - or as a "living identity", emphasizing daily life and the contemporary lifestyle of a community and leaving in the background a possible common past.

In that sense, European cultural identity could go on two ways - if not both-: to begin, cultural identity based on the past, history and common European heritage; on the other hand, the identity of the present-day Europe - centered on the EU and the common values and built the last decades. In both cases, herit-

\footnotetext{
Heid, Katherine (ed.) (2016), Culture, cities and identity in Europe, Brussels: European Economic and Social Committees, pp.48-50.

Peterková, Jana (2003), "The role of cultural heritage in the process of mutual communication and creation of consciousness of common cultural identity", Kakanien Revisted: last visit on the $12^{\text {th }}$ of August: http://www.kakanienrevisited.at/beitr/fallstudie/JPeterkova1.pdf
} 
age is a key element in the creation of a common cultural identity, not only in the EU but in the framework of any community.

Heritage is "that part of the past which we select in the present for contemporary purposes"8. These parts of the past use to be buildings, landscapes and pieces of art that refer to certain historic periods, persons or events and are preserved for its importance or symbolism. In the case of the EU, its Member States account for 286 sites of the UNESCO's World Heritage List, representing almost the $30 \%$ of the total ${ }^{9}$. This heritage uses to be related; sites are seen as exemplary of developments or phenomena present in larger regions, for example the Baltic, the Mediterranean or Eastern Europe. This suggests that these sub-European regions have their own shared histories. Relations between areas or countries are revealed when sites are described as crossroads or meeting places or when external and outward influences are indicated. This shows that there are historic relations between the countries and people in Europe ${ }^{10}$.

Certainly, the historical ties between the states of the present EU are many. Europe has been a continent in constant war and change, but also in constant exchange and feedback. From ancient Rome, where half the continent was united within an empire, to the Industrial Revolution, through the growth of cities in the Middle Ages, the colonial period or the unions between European dynasties in modern times. All this, besides, accompanied by artistic, aesthetic and philosophical currents that crossed the continent through the centuries ${ }^{11}$. To summarize these common historical roots - and on the other hand so well-known and studied - is a task that escapes our goal; nevertheless, it is possible to emphasize those general traits that during the centuries have been developing a set of common cultural values in Europe.

According to Anthony Smith ${ }^{12}$, the roots of this European values "paradigm" — very summarized- lie in ancient times, where principles, such as human activity or good, rational

8 Renes, Hans; Van Gorp, Bouke (2006), “A European cultural identity? Heritage and shared histories in the European Union", Tijsdchrift voor Economische en Sociale Geografie, vol. 98(3), p. 408.

Idem, op. cit., p. 409.

10 Heid, Katherine (ed.) (2016), op. cit.

11 For a general overview of the shared history of Europe: Renes, Hans; Van Gorp, Bouke (2006), op. cit., pp. 410-13.

12 Smith, Anthony D. (1995), "National identity and the idea of European unity", International Affairs (Royal Institute of International Affairs), vol. 68(1), pp. 58-59. understanding of humans etc. seemed to be given. Their background was formulated in the Middle Ages under the influence of Christianity and its principles of freedom, meaning the intellectual development and equality of people in the face of god, as well as the principle of individualism in the sense of personal responsibility to god. On the other hand, European intellectual life in modern times was determined by natural science, and mechanics that were mainly shaping the world; it was the period of establishing the system of European values including those of rationalism, freedom, activity of humans, humanism etc. Finally, the author states that the last centuries were influenced by the development of industrial technology, the so called scientific-technological revolution, and by the consciousness of globally connecting humans. The accent lies on individuality and its rights and freedom expounded in the unity of law and responsibility of each human being. The knowledge of global responsibility of mankind (ecology) becomes then the new principle.

As we can see, beyond the history or heritage shared by the different states, regions and communities of the EU, there seems to be a basis for what would be a European culture or a set of common values of the different European societies and communities that has been developing over time.

Further the past, today the EU, the context of its birth and its growth, have undoubtedly collaborated in the creation of a common cultural and values ideology shared by all its Member States. As Carlos Romero Giménez points out ${ }^{13}$, the relocation of Europe in the international political context — not being the geopolitical center anymore - the phenomenon of globalization and all its consequences and the economic and political unification assumed and achieved by the EU have had direct implications for the development of a united culture of values and a common identity.

This cultural and values unity shared by the EU Member States has reached areas such as education, politics or even law, with the socalled "culture of European law" relating to civil and criminal law and which consists of six elements: historicity, scientificity, independence of jurisdiction, confessional neutrality of the state, plurality and unity, particularity and

13 Giménez Romero, Carlos (1994), "El caleidoscopio cultural europeo: entre el localismo y la globalidad", Documentación Social, vol. 97, 11-18. 
universality ${ }^{14}$. Thus, we see a double aspect: on the one hand, a historical and cultural past that has left more or less an inheritance and a common collective memory and on the other hand a series of common values and identities that have been formed around the creation of the EU and have developed a culture or way of doing similar among all their communities.

Nevertheless, the visibility given to this cultural identity is usually partial. A study by the European Commission itself indicated that likewise in many monographs on European social, cultural or intellectual history, Europe still tends to be represented by the more extensively researched experiences of French, German and British men ${ }^{15}$. Earlier studies explicitly or implicitly identified Europe with its Western part. Today, historians include examples from the past of various European countries in their historical overviews; yet, these examples often serve as mere illustrations of a general trend, which is in fact understood through the analyses of the most-researched Western European countries. In fact, Western Europe still serves as the standard for comparison and evaluation. South Eastern Europe ('the Balkans') in particular, except for Greece, is absent in many volumes on European past. Indeed, there seems to be a discourse about what the European identity is that excludes other parts of the past.

Nevertheless, we could affirm that there is an actual European cultural identity because there is a common heritage and history but there is also a common present: the EU. One characteristic of this cultural identity, which is undoubtedly complex and seems not to be consolidated, is its plural basis. The European cultural identity is based on the dialogue, the respect and the coexistence of many identities and a wide cultural diversity.

\section{Pluralism and cultural diversity in the $\mathbf{E U}$}

\subsection{Recognition of cultural diversity: the process}

Once having looked at the question of cultural identity, a complex issue that is still

14 Häberle, Peter (2006), "Aspectos constitucionales de la identidad cultural", Derechos y libertades: revista del Instituto Bartolomé de las Casas, vol. 14, 95-97.

15 European Commission (2015), "Bridge over troubled waters? The link between European historical heritage and the future of European integration", EUR 27159 EN, pp. 23-25. being debated today, and trying to clarify its possible consistency, it is time to focus on the root: cultural diversity. If there is something characteristic of the EU, it is its cultural diversity and its respect and pride for it. Indeed, one of the hallmarks of the EU and one of the basic principles in identifying its identity is respect for cultural diversity and plurality. The EU has been able to establish itself and to be recognized as a united space in its plurality and diversity and, above all, a space for intercultural dialogue. Then, it is necessary to observe the normative framework on which this defense of diversity is based.

From the outset there have been two rhetoric around cultural diversity and identity in the Union ${ }^{16}$ : on the one hand the critical discourse, currently nourished by nationalisms, fair right and debates around the security and internal borders of the EU; on the other hand, there seems to be a rhetoric of an emotive tone, often only programmatic in scope and opposite to the previous one, about the Europe of diversity, the Europe of the peoples and cultures that live within it, a discourse that usually pivots on three guiding concepts: intercultural dialogue, cultural diversity and social cohesion as well-intentioned as, more often than not, ineffective.

Within the EU there has been a slow but gradual inclusion in its normative framework of legal guarantees to lost three concepts previously mentioned. We can see an aspiration towards the regulation of these concepts, although outside of anti-discrimination criminal laws, for example intercultural dialogue is not a legal category that is specifically regulated at national or international levels ${ }^{17}$. However, from this idea, the European Commission initiatives such as the Culture 2007-2013, Europe for Citizens programs or the Year of Intercultural Dialogue (2008) stimulated the dialogue of EU institutions with bodies such as the European Committee on Social Rights Council of Europe, the European Committee, UNESCO or civilian platforms which have insisted that such intercultural dialogue only takes place in an area where security, freedom, equal oppor-

\footnotetext{
16 García Cívico, Jesús (2013), “¿Hay realmente un horizonte intercultural en la Unión Europea?", Universitas: Revista de Filosofia, Derecho y Política, vol. 17, 97-138.

17 Ibidem.
} 
tunities and public participation are guaranteed $^{18}$.

The EU went from being an economic organization to being an organization with also political objectives. The Organization for Security and Cooperation in Europe (OSCE) adopted in 1990 the Copenhagen Declaration, which is considered the "European Charter of Minorities", which recognizes, among others, the right of every individual to express, preserve and develop freely their ethnic, cultural, linguistic or religious identity and to maintain and develop their culture in all its aspects, free of any attempt to assimilate against their will. Although this document contained only a declaration of principles, it did, at the time, represent a qualitative advance in that the question of the legitimacy of state policies of assimilation was explicitly raised. However, the participating states refused to commit themselves to the creation of concrete mechanisms to ensure the effective implementation of recognized rights. Nor did the "Charter of Paris for a New Europe" that year led to the establishment of specific control mechanisms to assess progress or setbacks in the situation of minorities in Europe. The functions assigned to the new figure of the High Commissioner for National Minorities were also more political than legal ${ }^{19}$.

Since 1993, the EU has insisted on its main policy documents in which both its internal and external policies are based on democratic values and respect for human rights. At that time, it was established that the stability of the institutions guaranteeing democracy, the rule of law, human rights and respect for and promotion of minorities is the first requirement that the countries aspiring to join the EU must meet. The Copenhagen Criteria ${ }^{20}$ that, in very brief terms, are those that have to fulfill a new state to integrate to the EU, contemplate citizens, geographical, political and economic criteria. The political criteria include issues of democracy, rule of law, human rights and respect for and protection of minorities. With this criterion, it was sought that the members belonging to these minorities maintained their

18 More information: Kunn, Theresa (2015), Experiencing European integration: transnational lives and European identity, Oxford: University Press Scholarship Online, pp. 40-62

19 BLoEd, A. (1995), "The OSCE and the issue of national minorities" in Phillips, A., Rosas, A. (ed.), Universal minority rights, London: Minority Rights Group, pp. 113-122.

$20 \mathrm{http} / / /$ europa.eu/rapid/press-release_DOC-93-3_en.htm culture and traditions, especially their language, and were not subjects of discrimination. Also in the 1990s, the Framework Convention for the Protection of National Minorities - a legally binding agreement - was adopted as the "European Charter for Regional or Minority Languages". Later, the Council of Europe's Cultural Cooperation Council began the development of the project "Democracy, Human Rights and Minorities: Educational and Cultural Aspects".

The Bolzano Declaration on the rights of national and linguistic minorities in the candidate countries to join the EU in the context of the 2004 enlargement provided 5 points: 1) to improve supervision of the Member States, 2 ) to integrate minority protection within human rights in the Member States' legislations (3) strengthening the EU as a community of values, (4)

improving cooperation between the EU, the Council of Europe and the OSCE, and (5) bringing constitutional life to the theme "united in diversity" 21 .

Today the EU is defined as a union that shares common values based on peace and coexistence and indivisible and universal values such as human dignity, freedom, equality and solidarity, all supported by democracy and the rule of law. The main recognitions of the cultural diversity and cultural identity within the EU are the Article 3 of the Treaty of the EU, which states that the Union respects its rich cultural, linguistic diversity, and ensure that Europe's cultural heritage is safeguarded and enhanced and also the Article 167 of the Treaty on the Functioning of the EU, which determines that "The Union shall contribute to the flowering of the cultures of the Member States, while respecting their national and regional diversity and at the same time bringing the common cultural heritage to the fore"22. The article continues and delivers a series of actions to be taken, such as promoting the history and culture of all the people of Europe, safeguarding heritage and cultural exchange, and promoting intercultural dialogue. The same article provides for the functioning of the institutions in this area when it comes to policy-making and is carried out by co-decision between the

\footnotetext{
KuHn, THeResa (2015), op. cit., p. 55.

22 Consolidated version of the Treaty on the Functioning of the European Union (C 326/47), Official Journal of the European Union, October 26, 2012.
} 
Council and Parliament after consulting the Committee of the Regions.

\subsection{Legal protection of the cultural rights}

Thus, as we have seen, the EU has emerged as a space of respect for cultural diversity. This is the basis of the intercultural model of the EU which we have written about that seeks to promote and defend plurality and diversity within its borders, making it a hallmark of the Union.

Beyond the mere political recognition of cultural diversity - the basis, as we have said, of that European cultural identity - there is a legal basis and protection of that same diversity. The so-called "cultural rights" are rights promoted to ensure that individuals and communities have access to culture and can participate in whatever is their choice. They are fundamentally human rights to ensure the enjoyment of culture and its components in conditions of equality, human dignity and non-discrimination. They are rights related to issues such as language; cultural and artistic production; participation in culture; cultural heritage; copyright; minorities, among others ${ }^{23}$. The role of cultural rights in the establishment of cultural identity is paramount.

Next, we will focus on two main treaties on cultural rights: the European Convention on Human Rights ${ }^{24}$ and the Charter of Fundamental Rights of the $\mathrm{EU}^{25}$.

When thinking about cultural rights in relation to the European Convention, we must bear in mind that, at the origin of this legal text, these rights are not found but others of much greater weight from the civil and political point of view, and which are what have justified the drafting of this important legal instrument $^{26}$.

However, while the ECHR does not take into account cultural rights and freedoms in the first instance, following the intense development of the instrument, which is wellknown in the case-law of the European Court of Human Rights, there is no doubt that nu-

23 Arroyo Yanes, Luís Miguel (2015), "Los derechos culturales como derechos en desarrollo: una aproximación", Nuevas Políticas Públicas: Anuario multidisciplinar para la modernización de las Administraciones públicas, p. 264.

24 Council of Europe (2010), European Convention on Human Rights, Strasbourg: European Court of Human Rights.

25 Charter of the Fundamental Rights of the European Union (200/C 364/01), Official Journal of the European Coтmunities, December 7, 2000.

26 Arroyo Yanes, Luís Miguel (2015), op. cit., p. 265. merous points of relationship and contact have arisen between the rights and public freedoms protected by the Convention and the rights and freedoms that we can conceptualize as cultur$\mathrm{al}^{27}$.

According to Luís Miguel Arroyo, it is necessary to isolate the cultural dimension in some of the fundamental rights and freedoms that the Convention protects, not evidently in all of them, since many of the recognized ones can hardly get a relationship, even weak, with cultural rights. The degree of penetration of the cultural footprint will depend on the contacts that can be established between each of the cultural rights and the rights and freedoms protected by the Convention and this degree is presented a priori as quite uneven ${ }^{28}$.

The points of contact between rights protected by the ECHR and cultural rights are therefore limited and circumscribed. They are restricted to the cultural dimension that may be found in the human rights protected by the Convention. These points of contact would include, among others: the right to a fair trial (article 6), respect for privacy (article 8), freedom of peaceful assembly (article 11), freedom of expression in relation to artistic creation (article 10) as well as the right of ownership in relation to works of art (article 1 of Protocol I) ${ }^{29}$.

Another legal text with great relevance is the Charter of Fundamental Rights of the EU, resulting from the works of the European Convention. In view of the way in which cultural rights are considered in the Charter, it should be noted that the imprint of the double nature of this instrument, both international and with an intended or potential constitutional character, is particularly noticeable. Either from one perspective or from another, we can reach the same conclusion: the recognition of cultural rights does not occur, as would have been desirable, in a global and detailed way at the same time, but in a very limited and dispersed way, with a marked lack of clarification and definition, which favors very little the emergence and consolidation of a true system at the highest legal level ${ }^{30}$.

Alongside the protection of human dignity - on the basis of which legal doctrine usually draws the cultural identity of individuals - a




number of rights are protected, all of which are well-known because they are present in European constitutional texts and, mostly, in International texts that have served to inspire it. Thus, we find references to rights as deeply rooted as those linked to the arts, whether rights or freedoms, and to scientific research (II-73), freedom of thought, conscience and religion (II-70) right to education (II-74), human dignity (II-61) and freedom of expression (II71 ), etc ${ }^{31}$. The Charter, on another level, imposes on the Union the protection of cultural, religious and linguistic diversity (II-82), a novelty which, because of its connection with cultural rights, should be particularly highlighted. If the Union protects cultural diversity, such a provision should be understood, under cover of international texts, in particular bearing in mind the UNESCO Declaration on Cultural Diversity and the Convention protecting Cultural Expressions, such as the Union protecting cultural rights within the European Community and, which seems equally relevant, that a reading of them is made as a framework conducive to cultural diversity itself, with human rights being the guarantors of aforementioned cultural diversity. It seems that there is sufficient evidence to consider that the protection of cultural diversity is in some way protecting cultural rights as such, and that a "cultural key" reading of the whole set of public rights and freedoms that are recognized at European level. This is the breakthrough of the Charter: the strengthening of the principle of cultural diversity, and with it, the cultural rights of people living in Europe.

\section{EU action for a common cultural identity}

\subsection{Cultural policies}

As we have seen, there is a legal basis in the EU that, with greater or lesser effectiveness or completeness, provides protection for plurality and cultural diversity. On the other hand, when we talk about politics, we observe that there is no common cultural policy in the EU, although as we have seen in article 167 of the TFEU, there is a mechanism of action, by which the Council - by qualified majority - and the Parliament may propose measures, after con-

31 Charter of the Fundamental Rights of the European Union (200/C 364/01), op. cit. sulting the Committee of the Regions, for the implementation of a policy. This action, however, is applied taking into account the principle of subsidiarity, meaning that the EU will only intervene in shared competences - as in the case of cultural matters - when the objectives of the intended actions are not achieved by the Member States.

Thus, from the EU's more limited capacity for cultural policy-making, in this section we will discuss some of the most important policy actions carried out in the field of culture. Emphasis will be placed on those policies aimed at reinforcing cultural identity and that "common cultural heritage" referred to in the article 167.

The starting line will be 2005, when the draft of the European Constitution failed, opening the debate on European identity and the limits of it. Indeed, after the negative vote in the referendums held in France and the Netherlands on the European Constitution in June 2005, the European Council began the period of reflection on how to proceed with institutional reform. What happened proved that communication between the European institutions and their citizens was not very good; or rather that the Union and its citizens did not understand each other. In response, on 13 October 2005, the Commission proposed the Plan $D$ for Democracy, Dialogue and Debate ${ }^{32}$ with its respective Commission action plan on improving communication on Europe which was intended to involve European citizens in the debate on the future of the EU and its policies.

The Commission's idea was that this Plan $D$ would be complementary to other initiatives addressed to the European citizens, particularly in the areas of education, youth, culture and the promotion of active European citizenship. The aim was to restore public confidence in the EU through the organization of national debates and through various community-level initiatives $^{33}$.

In an information note entitled Plan $D-$ Wider and Deeper Debate on Europe, the Commission drew the conclusions of the first year of the program. The central idea of the Plan $D$ consisted on "listening better", "explaining

\footnotetext{
32 "European Commission launches PLAN D for Democracy, Dialogue and Debate", Press Release Database, Brussels, October 13, 2005: http://europa.eu/rapid/press-release_IP05-1272_en.htm

33 Peterkoví, Jana (2003), op. cit., pp. 4-8.
} 
better" and "affecting the local sphere"" 34 . The intention was to foster a broad public debate through the visits of the Commissioners to the Member States, through the European Round Tables for Democracy, better use of the Europa Direct network and through the European Goodwill Ambassadors (similar to the United Nations).

It also wanted to promote citizens' participation in the democratic process through the program Europe for Citizens ${ }^{35}$, improving the transparency of institutions and their procedures and increasing voter turnout. In addition, we anticipated a better use of Internet technologies to actively debate and defend European policies in cyberspace, within projects such as Tomorrow's Europe, Our message to Europe o Our Europe - Our Debate - Our Contribution. There was also a special Eurobarometer survey on the "future of Europe" 36 .

The process of reflection came to an end in June 2007 when the European Council, during the German Presidency, agreed on a mandate for a new intergovernmental conference (IGC) aimed at finding a solution to agree on a new Reform Treaty. The IGC was concluded in October of this year and the Treaty of Lisbon was signed in December 2007. The conclusion reached after several initiatives and several surveys is that the EU needed to communicate with its citizens through the audiovisual media $^{37}$. The first step of the European Commission was to create an audiovisual portal with current news and topics of interest. It also created a space on YouTube called EU Tube. And to be able to listen to what the citizens wanted to say was created the portal Your Voice in Europe ${ }^{38}$. What was wanted to try with all these proposals and actions was to bring institutions closer to the citizens to make them participate in the EU and to forge greater complicity in the end, so that the European citizens would identify more with the EU, its values and its projects.

Leaving the scope of citizen participation, and following chronologically, there have

34 Idem 31.

35 "Europe for Citizens Programme", EU Citizens Portal (European Commission): http://ec.europa.eu/citizenship/ europe-for-citizens-programme/

36 Peterková, Jana (2003), op. cit., pp. 4-8.

37 Ibidem.

38 "Your Voice in Europe: new Commission portal aims to give citizens a bigger role in policy making", Press Release Database, Brussels, January 27, 2007: http://europa.eu/rapid/ press-release_IP-03-122_en.htm?locale $=\mathrm{ca}$ been several cultural policies more to highlight briefly:

The first one is the European Heritage Label $^{39}$, which was initially set up as an intergovernmental initiative between several Member States in 2005. At the request of the Member States, the Commission proposed in 2010 that the European Heritage Label formally became an initiative of the EU. The Label was established by Decision 1194/2011 / EU. Its general objective is to strengthen intercultural dialogue and the feeling of belonging to the Union of European citizens. To achieve these objectives, the sites are selected for their great symbolic value, the role they have played in the history and culture of Europe and the EU and its relationship with democratic principles and human rights ${ }^{40}$.

The next action of the EU to highlight is the European Agenda for Culture ${ }^{41}$. Since 2007, the Agenda has been the strategic framework for action by the Union in the field of culture. It is based on the promotion of three strategic objectives: 1) cultural diversity and intercultural dialogue; 2) culture as a catalyst for creativity; and 3) culture as a vital element in international relations. The central methods of the Agenda are the dialogue with stakeholders in the culture sector and the open method of coordination. In the Culture Plan of Work 2015-2018, the Agenda is further elaborated, and four priorities are set: 1) accessible and inclusive culture, 2) cultural heritage, 3) cultural and creative sectors, creative economy and innovation and 4) promotion of cultural diversity. Priorities are put into practice in 20 concrete measures ${ }^{42}$.

The Commission's Communication "Towards a EU Strategy for International Cultural Relations" presented by the Commission and the High Representative of the Union for Foreign Affairs and Security Policy in 2016 aimed

39 "European Heritage Label: what is it?", Creative Europe's Portal (European Commission): https://ec.europa.eu/programmes/creative-europe/actions/heritage-label_en

40 Decision 1194/2011/UE of the European Parliament and of the Council of 16 November 2011 establishing a European Union action for the European Heritage Label, Official Journal of the European Communities, November 22, 2011.

${ }^{41}$ "Strategic framework - European Agenda for Culture", Culture's Portal (European Commission): https://ec.europa. $\mathrm{eu} /$ culture/policy/strategic-framework en

42 European Commission (2014), "Conclusions of the Council and of the Representatives of the Governments of the Member States, meeting within the Council, on a Work Plan for Culture (2015-2018)" (2014/C 463/02), Official Journal of the European Union, vol. 57, 4-14. 
at promoting cooperation between the Union and its partner countries and the promotion of a world order based on peace, the rule of law, freedom of expression, mutual understanding and respect for fundamental values ${ }^{43}$.

Intercultural dialogue is a permanent priority for the Union. And, with the entry into force of the Lisbon Treaty, this dimension became even more important. In the specific field of cultural policy, initiatives such as the one concerning Romanian culture, intercultural cities and the dialogue with the Platform for Intercultural Europe. Other Union policies promoting intercultural dialogue are those relating to the audiovisual sector, multilingualism, youth, research, integration and external relations, to name just a few. The best known, however, is probably the European Capitals of Culture ${ }^{44}$.

Finally, we cannot fail to mention one of the flagship programs of the EU in the field of higher education: the Erasmus Programme. Its birth was in 1987 and has proved to be a real success; this is why in 2014 - we are thus, in this last decade of intense activity in the cultural policy of the Union-Erasmus + was created $^{45}$, a new program combining all the EU's current schemes for education, training, youth and sport. Very briefly, it should be noted that this project has provided the possibility of issuing joint degrees between universities in different countries, the exchange of faculty, students and staff of higher education institutions, the exchange of ideas and resources, the development of transnational projects or the adoption of a common system of European credits to measure results and the volume of study. But, without any doubt, what the program is best known for is student mobility, which is the basis of the program's ideology, that seeks to homogenize a key sector: future generations, which, thanks to programs like this, grow with a stronger sense of European identity ${ }^{46}$.

43 Ibidem.

44 "European Capitals of Culture", Creative's Europe portal (European Commission): https://ec.europa.eu/programmes/ creative-europe/actions/capitals-culture_en

45 Erasmus + Portal: https://ec.europa.eu/programmes/erasmus-plus/

46 GonzÁlez, Julia (2003), “¿Qué subyace en las políticas europeas? Objetivos institucionales en la construcción de la identidad europea", in Gómez-Chacón, InÉs MARÍA (ed.), Identidad europea: individuo, grupo, sociedad, Bilbao: Universidad de Deusto, 97-108.

\subsection{European Year of Cultural Heritage 2018}

Finally, a final analysis of a new and very recent initiative of the EU will be carried out: the European Year of Cultural Heritage 2018 - hereinafter European Year-. This initiative is a clear example of the path the EU is pursuing - and which it has followed in recent years as it has been shown above- in cultural matters and above all the efforts are being made to strengthen and promote identity and cultural heritage Common. Under the motto "celebrating the diversity and richness of our European heritage" 47 , the initiative was proposed in 2014 by the Council and was rapidly accepted and developed through a proposal by the European Commission and received full support from the European Parliament.

The official Decision - that is to say the publication of the legislative act officially approving the European Year initiative - did not happen until very recently; specifically, it was approved on May 17, 2017 48 , so the initiative is currently in preparation and development.

However, the general characteristics of the European Year are known. On the one hand, the objectives of the initiative are to promote cultural diversity, intercultural dialogue and social cohesion; to underline the economic contribution of cultural heritage; and to emphasize the role of cultural heritage in the EU's external relations, as well as in conflict prevention or post-conflict reconciliation ${ }^{49}$. The proposal, moreover, arose with two specific purposes: to raise awareness of European history and values and to strengthen a sense of European identity; and to draw attention to the opportunities offered by the European common cultural heritage but also the challenges, such as the impact of digital shift, the environmental and physical pressure on heritage sites and the illicit trafficking of cultural objects.

47 Both the Commission and the Council have in their web pages a space dedicated to this initiative. This information is very generic, and we can find there the information such as the objectives, the aim or financing question, as well as promotional videos. For the Commission's website: https:// ec.europa.eu/culture/european-year-cultural-heritage-2018; and for the Council's one: http://www.consilium.europa.eu/ en/press/press-releases/2017/02/09-cultural-heritage/.

48 Decision 2017/864 of the European Parliament and the Council of 17 May 2017 on a European Year of Cultural Heritage (2018), Official Journal of the European Union, May 20, 2017.

49 Idem 46. 
In addition, the project will have a budget of eight million euros.

If we look at the Decision (EU) 2017/864 establishing the launch of the European Year, article 1 is a declaration of intent and it is worth noting it: "to encourage the sharing and appreciation of Europe's cultural heritage as a shared resource, to raise awareness of common history and values and to reinforce a sense of belonging to a common European space" ${ }^{50}$. In these words, we can see how the EU itself is implying the two types of identities we discussed in the first section of the paper. On the one hand, that historical identity that is denoted in the appreciation of the cultural heritage of Europe and its common history; and on the other hand, the living's identity, which is based on the present and those values and features that two or more communities share in their coexistence or in their future project. That is exactly what the article refers to when it speaks of the reinforcement of the sense of belonging to a common European space, being the EU this space.

Leaving behind the second article, which deals with the objectives already mentioned, the third article ${ }^{51}$ deals with the measures to be taken both at the community level and at national, regional and local level. Some of these are debates and conferences around the common European heritage (1b) or the launching of exhibitions and educational projects in the same direction (1c), all promoting the use of social and media networks.

The next article is the fifth $^{52}$, which provides the coordination at the EU level for the proper functioning of the initiative. Basically, the article confers on the European Commission the leading role, being the institution responsible for meeting and coordinating the actions with the Member States - which should have their own coordinators-. As we see, shared competences in the field of culture are clearly reflected. Parliament, for its part, may join the meetings as an observer.

The European Year is thus a clear example of the cultural policies and more specifically the work of cultural identity that the EU has been developing in the last decade and re-

50 Decision 2017/864 of the European Parliament and the Council of 17 May 2017 on a European Year of Cultural Heritage (2018), Official Journal of the European Union, May 20, 2017, p. 4.

51 Idem, op. cit., p. 6.

52 Ibidem. flects the will of the Union - which does not have to be the same of the Member Statesto strengthen common cultural ties. However, why has the Union now decided to establish a European Year, when it already has, as we have seen, different programs and initiatives? In what context should we place it?

Indeed, the European Year initiative is part of a complex and convoluted time for the EU. The economic crisis, the rise of nationalism and far-right, Brexit or the refugees' crisis has led to a critique of the economic and political model of the Union, as well as a questioning of its values, its limitations and its true identity. Professor Alejandro del Valle Gálvez, in one of his studies ${ }^{53}$, attributes this lack of power or enthusiasm within the EU to the lack of sense of process, meaning the feeling that the EU does not evolve, the feeling that the project is stopped.

In this sense, everything suggests that the initiative of the European Year could be a push by the Union to the European project, in this case through cultural heritage and collective identity. Such initiatives like these can make the Union feel stronger in these convulsive moments when the EU must consider its strategy for the future. And the enhancement of common values, historical and cultural ties seems a good way.

\section{Conclusions}

The subject of study of this work is not simple; it is a broad question, always open to debate and where reaching closed and tight conclusions seems impossible. Issues such as cultural diversity or identity are disciplines that involve many factors such as geopolitics, politics, history or even philosophy. However, from this work we can draw some conclusions.

It is clear that the EU is a multicultural space, where many traditions, languages, religions, ethnicities and ways of understanding coexist; definitely, many identities. The EU is a space of respect with a clear intercultural model. In the EU, there is a respect for this cultural diversity and where intercultural dialogue is promoted. Such interculturalism implies a

\footnotetext{
For a deeper development of the concept: VAlLE GÁlVEZ, AlEJANDRo Del (2013), "Europa más allá de la unión: pacto confederal y nuevo relato europeo", Teoría y Realidad Constitucional, vol. 32, pp. 346-349.
} 
management model based on equality and respect, where political and legal structures have been created to guarantee such interaction, unlike the multicultural model, which simply advocates for peaceful coexistence. The EU with its intercultural model aims to go further, enriching different cultures and identities through this intercultural dialogue.

Beyond respect for cultural diversity and different identities within the EU, the debate on the existence of a common European cultural identity is complex and a closed conclusion cannot be reached. The common legacy of the different territories within the EU through their past and their heritage is a fact; however, this is not enough to affirm that there is a common identity. The recent events of the last decade have shown that the construction of cultural identity involves not only historical and past events but also geopolitical and present events. In that sense, the construction of a common European identity seems to depend more and more not only on the past but also on the present and the future, on the common values and on the common project that the EU embodies.

Connected with the previous points, the past of Europe is stained of constant wars and conflicts between neighboring regions during centuries. The EU was born to avoid precisely that; the EU embodies the values of peace, respect and coexistence between equal but different territories. In that sense, intercultural dialogue is essential to create that European consciousness of unity in the diversity that leaves behind their differences for the good of all. In addition, the recent events in the last decade that have led the EU to a certain degree of pessimism and questioning its meaning have shown us that the EU needs to work harder on this path to strengthen the common project beyond the economy or politics.
Furthermore, the EU, through its process and its growth as a space not only in the economic field, has created political and legal structures that guarantee the recognition of cultural diversity and its protection. As we have seen, there is an endowment of instruments that respond to that plural reality represented by the EU. However, for many years the Union has been based on creating institutions and structures, leaving aside that work more focused on values and identity. The failure of the European Constitution was a turning point in this sense, as has been seen, and since then many policies, projects and cultural initiatives have been put in place to reinforce and promote the more humane and philosophical side of the EU.

In terms of culture, the EU does not have full competences, exemplifying very clearly that culture is and should be shared, treated at supranational and national level. In terms of cultural identity, the promotion of a common identity with the maintenance of national and regional identities does not seem incompatible. However, this depends mainly on national interests, since the principle of subsidiarity applies in the field of culture. If we focus on the work of the EU, it seems that it is working in the recent years on this path: the construction, promotion and reinforcement of a common cultural identity. The European Year of Cultural Heritage 2018 is a clear example of intercultural dialogue and the promotion of cultural and identity bonds.

Finally, in connection with the last two points, in order to promote that intercultural dialogue of which the EU is or wants to be a referent, the role of the Committee of the Regions seems crucial. This institution has currently advisory functions in the field of cultural policies, but it stands as an essential instrument for intercommunication between regions, identities, Member States and the EU. 


\section{Bibliography}

Arroyo Yanes, Luís Miguel (2015), "Los derechos culturales como derechos en desarrollo: una aproximación", Nuevas Políticas Públicas: Anuario multidisciplinar para la modernización de las Administraciones públicas, 263-283.

Bloed, A. (1995), "The OSCE and the issue of national minorities" in Phillips, A., Rosas, A. (ed.), Universal minority rights, London: Minority Rights Group.

Charter of the Fundamental Rights of the European Union (200/C 364/01), Official Journal of the European Communities, December 7, 2000.

Consolidated version of the Treaty on the Functioning of the European Union (C 326/47), Official Journal of the European Union, October 26, 2012.

Council of Europe (2010), European Convention on Human Rights, Strasbourg: European Court of Human Rights.

Decision 1194/2011/UE of the European Parliament and of the Council of 16 November 2011 establishing a European Union action for the European Heritage Label, Official Journal of the European Union, November 22, 2011.

Decision 2017/864 of the European Parliament and the Council of 17 May 2017 on a European Year of Cultural Heritage (2018), Official Journal of the European Union, May 20, 2017.

Dobbernack, J., Modood, T. (2011), "Tolerance and cultural diversity in Europe: theoretical perspectives and contemporary developments" in Tolerance, pluralism and social cohesion: responding to the challenges of the $21^{\text {st }}$ century in Europe - ACCEPT PLURALISM, Florence, European University Institute.

European Commission (2005), "European Commission launches PLAN D for Democracy, Dialogue and Debate", Press Release Database. Last visit on the 18th of August: http://europa.eu/rapid/press-release_ IP-05-1272 en.htm

European Commission (2014), "Conclusions of the Council and of the Representatives of the Governments of the Member States, meeting within the Council, on a Work Plan for Culture (2015-2018)" (2014/C 463/02), Official Journal of the European Union, vol. 57, 4-14.

European Commission (2015), "Bridge over troubled waters? The link between European historical heritage and the future of European integration", EUR $27159 \mathrm{EN}$.

García Cívico, Jesús (2013), ¿Hay realmente un horizonte intercultural en la Unión Europea?”, Universitas: Revista de Filosofia, Derecho y Política, vol. 17, 97-138.

Giménez Romero, Carlos (1994), "El caleidoscopio cultural europeo: entre el localismo y la globalidad", Documentación Social, vol. 97, 9-34.

González, Julia (2003), ¿Qué subyace en las políticas europeas? Objetivos institucionales en la construcción de la identidad europea”, in Gómez-Chacón, Inés María (ed.), Identidad europea: individuo, grupo, sociedad, Bilbao: Universidad de Deusto, 97-108.

Häberle, Peter (2006), “Aspectos constitucionales de la identidad cultural”, Derechos y libertades: revista del Instituto Bartolomé de las Casas, vol. 14, 89-102.

Heid, Katherine (ed.) (2016), Culture, cities and identity in Europe, Brussels: European Economic and Social Committees.

Kuhn, Theresa (2015), Experiencing European integration: transnational lives and European identity, Oxford: University Press Scholarship Online.

Lucas, Javier de (2006), "Sobre la gestación de la multiculturalidad que resulta de la inmigración" in Serafí, J., Gimeno, C. (ed.), Migración e interculturalidad. De lo local a lo global, Castellón de la Plana: Universitat Jaume I, 34-59.

Peterková, Jana (2003), "The role of cultural heritage in the process of mutual communication and creation of consciousness of common cultural identity", Kakanien Revisted: last visit on the $12^{\text {th }}$ of August: http://www.kakanien-revisited.at/beitr/fallstudie/JPeterkova1.pdf

Renes, Hans; Van Gorp, Bouke (2006), "A European cultural identity? Heritage and shared histories in the European Union", Tijsdchrift voor Economische en Sociale Geografie, vol. 98(3), 407-415.

Smith, Anthony D. (1995), "National identity and the idea of European unity", International Affairs (Royal Institute of International Affairs), vol. 68(1), 55-76.

Valle Gálvez, Alejandro del (2013), "Europa más allá de la unión: pacto confederal y nuevo relato europeo", Teoría y Realidad Constitucional, vol. 32, pp. 341-355. 